\title{
EFFECTS OF CROSS-BORDER MERGERS AND ACQUISITIONS ON GDP PER CAPITA AND DOMESTIC INVESTMENT IN TRANSITION COUNTRIES
}

\author{
Jelena ZVEZDANOVIĆ LOBANOVA ${ }^{*}$, Davorin KRAČUN ${ }^{2}$, Alenka KAVKLER ${ }^{3}$ \\ ${ }^{1}$ Institute of Social Sciences, Kraljice Natalije 45, Belgrade, Serbia \\ ${ }^{2,3}$ Faculty of Economics and Business, University of Maribor, \\ Razlagova 14, Maribor, Slovenia
}

Received 26 March 2017; accepted 20 November 2017

\begin{abstract}
The study investigates the impact of cross-border mergers and acquisitions on GDP per capita and domestic investment in 22 European transition countries from 2000 to 2014 by using the system Generalized Method of Moments estimator. The main implications are that cross-border mergers and acquisitions have a negative effect on GDP per capita in the year of merger or acquisition, while their lagged level shows a positive impact. From long-term perspective, this type of FDI has negative and significant effect on GDP per capita. The results show that one-year lagged cross-border mergers and acquisitions positively affects domestic investment, suggesting that spillover effects of this type of investment can be expected not earlier than one year after the merger or acquisition. The value of this paper is that our results show how the advances in structural reforms enhance GDP per capita whereas their influence on domestic investment activity is insignificant. We found that there is insignificant impact of the relationship between overall structural reforms and cross-border mergers and acquisitions on GDP per capita and domestic investment both in short and long run. The originality of this study lies in investigation of the dynamic nature of cross-border mergers and acquisitions and their economic effects depending on the quality of structural reforms.
\end{abstract}

Keywords: cross-border mergers and acquisitions, structural reforms, GDP per capita, domestic investment, transition countries, system GMM.

JEL Classification: E22, F21, F23, O52.

\section{Introduction}

Foreign direct investment (FDI) represents an important development factor for each economy and the basic mechanism of global economic integration. Its inflow is crucial for all host countries, especially for those involved in the process of transition to a market economy. From the very beginning of their transformation, transition countries focused their attention on large-scale FDI mobilization, since they did not have enough of their own resources to

*Corresponding author. E-mail: jzvezdanovic@idn.org.rs 
finance the costly imitative model of technological modernization (Kulikova, Lobanov 2011). They created conditions to attract multinationals and the growth of cross-border mergers and acquisitions (C-B M\&A) activity as the dominant mode of foreign entry, by creating incentives such as customs and tax exemptions or direct investment incentives for foreign investors (UNCTAD 2003). Their expectations regarding the benefits of FDI are related to a change in the production structure (particularly evident in countries in transition), the establishment of efficient management and control systems, job creation, the transfer of experience, knowledge and modern innovative technologies, and export growth with an increase in overall competitiveness (United Nations 2003).

The experiences of post-socialist countries during their transformation into democratic states with a market economy show that their success has largely depended on the quality of institutional setting (Efendić et al. 2010; Beck, Leaven 2005). Many of them paid a high price for inefficient reform policies, especially in the first years of transition. Their reform performance depended on the legacy of macroeconomic distortions, poor market experience, involvement in serious regional conflicts, and their remoteness from the international market (De Melo et al. 1997). Building institutions in the context of rapid change did not represent the best solution for the transformation of their economic systems. Institutional capacity and the quality of macroeconomic policy were easily undermined by the rapid process of democratization in countries with a poor tradition of law and order (Polterovich, Popov 2007). This trade-off between democratization and developmental goals (such as democracy, participation in decision-making, and civil society) adversely affected the rate of economic growth. Economic reforms in transition countries were hindered by institutional traps like inefficient but stable norms of behaviour (Polterovich 2008). These obstacles to the reform process created a path of development that prevented the further progress of transition countries in the field of structural reforms.

The aim of this paper was to investigate the magnitude of economic effects of C-B M\&As on GDP per capita and domestic investment in 22 European transition countries for the period 2000-2014. We also included the interaction term with overall structural reforms in order to assess the conditional effects of C-B M\&As on GDP per capita and domestic investment. We took into account the fact that structural adjustment in European transition countries took place within a framework of international capital flow liberalization. This means that institutional double shock affected the features of economic development of these countries and, thus, determined the economic effects of C-B M\&As.

The rest of the paper is structured as follows. Section 1 contains a brief review of the recent empirical studies concerning the influence of FDI inflows on economic growth and domestic investment. Data and research methodology are presented in Section 2. Section 3 gives the empirical results followed by concluding remarks.

\section{Literature review}

Since the end of the 1970s, the majority of researchers have focused attention on the economic effects of FDI as the crucial factor in explaining the differences in development between countries. Empirical studies on the relationship between FDI (as well as its components) 
and economic growth reveal contradictory results. The majority of authors have found evidence that FDI inflows have a positive or neutral effect on host country economic growth. For instance, Hlavacek and Bal-Domanska (2016) reported the positive influence of FDI on economic growth of the Central and Eastern European (CEE) countries. Pegkas (2015) examined the effects of FDI on economic growth in the Eurozone countries for the period from 2002 to 2012. The author revealed that FDI stock is important factor that positively influences the economic growth. Alguacil et al. (2011) argued that FDI had a positive effect on output growth but its impact depended on internal and external macroeconomic stability and the quality of institutions.

Similarly, Jude and Levieuge (2017), in a study of 93 developing countries from 1984 to 2009, found that FDI alone had no significant effect on growth in developing countries, while a favourable institutional environment induced a growth-enhancing effect. Albulescu (2015) revealed that FDI and portfolio investment exerted a positive impact on long-term economic growth in 13 CEE countries for the period between 2005 and 2012. This result is contradictory to the findings of Eren and Zhuang (2015), who found that FDI (as well as M\&As and greenfield investment) did not have significant growth effects in 12 new member states of the European Union (EU) from 1999 to 2010. They pointed out that the growth effects of M\&As and greenfield investment depended on the availability of absorptive capacities in the host countries. On the other hand, Herzer (2012) indicated that FDI produced negative effect on growth in 44 developing countries and its impact varied considerably from one country to another. By using a general-to-specific model-selection approach, the author revealed that such large differences in the growth effects of FDI were mainly due to country specific factors like freedom from government intervention, business freedom, FDI volatility, and primary export dependence. The empirical study of Azman-Saini et al. (2010) provided evidence that FDI by itself does not have positive effect on economic growth and this impact depends on the level of economic freedom in recipient countries.

The empirical studies dealing with the influence of FDI on domestic investment also provide mixed results. In the recent empirical study based on firm- and industry-level data for the period 2003-2011 by Amighini et al. (2017), the authors showed that FDI produced positive spillovers on total investment, in particular within the recipient industries. Farla et al. (2016) investigated the impact of institutional quality in mediating the economic effect of FDI on domestic investment activity in 46 developing countries from 1996 to 2009. They found that FDI has a crowding-in effect, while its interaction with "good governance" causes negative megiation effect on domestic investment. Gocer et al. (2014) argued that FDI had a crowding-in effect on domestic investment in Asian, Latin American and Caribbean countries, while it had crowding-out effects in African countries. Mileva (2008) demonstrated that FDI had higher crowding-in effect in transition countries with less developed financial markets and weak institutional setting. Other transition countries which entered the final stage of transition process could rely on the foreign loans for raising domestic capital formation. Tan et al. (2016) evaluated the effects of inward and outward FDI on domestic investment using panel data of ASEAN-8 countries. With the help of pool mean group analysis, the authors found that both inward and outward FDI have a positive long-run impact on the gross domestic investment. 
On the other hand, the assessment of 4 CEE transition countries by Szkorupová (2015) provided evidence that FDI had a negative effect on domestic investment. The empirical studies by Wang (2010) and Adams (2009) revealed that FDI had a negative and current effect on domestic investment, while the cumulative effect of FDI over time tends to be positive. Kosova (2010) found that foreign entry had a negative effect on the growth and survival of domestic firms from the Czech Republic between 1994 and 2001. Her findings revealed that crowding-out was a short-term or static phenomenon, suggesting that initial foreign entry increased the exit rates of domestic firms. The author also pointed out that domestic firms enjoyed benefits from a foreign presence over time. These findings are consistent with the results of Jude (2014), who demonstrated that FDI also crowded out domestic investment, but its impact weakens over time. By considering the effects of two types of FDI on domestic investment on the sample of 10 CEE countries from 1990 to 2010, she found that greenfield FDI might develop long-term complementariness with domestic investment, while mergers and acquisitions did not have any significant effect on domestic investment. Pilbeam and Oboleviciute (2012) argued that FDI did not have negative spillovers on domestic enterprises in the new EU member states, while it makes negative contribution in the EU-15. Ashraf and Herzer (2014) estimated the effects of greenfield investment and C-B M\&As on domestic investment for the period 2003-2011 for 100 developing countries. Their findings indicated that greenfield investment has a marked negative effect on domestic investment, while M\&As do not have a significant impact. Sikharulidze et al. (2015) showed that FDI discourages domestic investment in Georgia through channels like competition in the product and financial market or via superior technology.

\section{Model specification, data and research methodology}

For the evaluation of the economic effects of C-B M\&As, we used C-B M\&As as an explanatory variable and tested it with the help of dependent variables like GDP per capita and domestic investment. We estimated the effect of this type of FDI on GDP per capita by employing this form of panel model specification:

$$
\begin{aligned}
& \log \left(G D P p c_{i t}\right)=\beta_{0}+\beta_{1} \log \left(G D P p c_{i t-1}\right)+\beta_{2} M \& A s_{i t}+ \\
& \beta_{3} M \& A s_{i t-1}+\beta_{4} R E F_{i t}+\beta_{5} M \& A s_{i t} \cdot R E F_{i t}+\beta_{6}{ }^{T} C O N_{i t}+\varepsilon_{i t},
\end{aligned}
$$

where the subscript $i$ denotes the $i^{\text {th }}$ country $(i=1 \ldots 22)$; the subscript $t$ denotes the $t^{\text {th }}$ year $(t=1 \ldots 15) ; \beta_{0}$ to $\beta_{6}$ are regression coefficients; Transposed vectors are denoted by $T$; $\varepsilon_{i t}$ are the error terms; GDPpc $c_{i t}$ represents the GDP per capita (in the natural logarithm); $G D P p c_{i t-1}$ is the lagged dependent variable; $M \& A s_{i t}$ stands for C-B $M \& A s$ as a percentage of GDP; $M \& A s_{i t-1}$ is the lagged variable; $R E F_{i t}$ is the overall structural reform indicator; $M \& A s_{i t} \cdot R E F_{i t}$ is the interaction term between the overall structural reform indicator and $\mathrm{C}-\mathrm{B} M \& A s$, and $C O N_{i t}$ is a vector of growth determinants including:

- government balance $\left(\right.$ Budget $\left._{i t}\right)$;

- domestic investment as a percentage of GDP $\left(D I_{i t}\right)$;

- GDP per capita PPP in 1989 US\$ (in the natural logarithm) ( Income $_{i t}$ ), and

- domestic credit to the private sector as a percentage of GDP (Credit $\left.{ }_{i t}\right)$. 
To quantify the economic effect of C-B M\&As on domestic investment, we utilized the following panel model specification:

$$
\begin{aligned}
& D I_{i t}=\beta_{0}+\beta_{1} D_{i t-1}+\beta_{2} M \& A s_{i t}+\beta_{3} M \& A s_{i t-1}+ \\
& \beta_{4} R E F_{i t}+\beta_{5} M \& A s_{i t} \cdot R E F_{i t}+\beta_{6}{ }^{T} C O N_{i t}+\varepsilon_{i t},
\end{aligned}
$$

where $D I_{i t}$ represents domestic investment calculated as the difference between gross fixed capital formation and FDI inflows; $D I_{i t-1}$ is the lagged dependent variable, while $C O N_{i t}$ is a vector of investment determinants including:

- lagged GDP growth (Growth it-1 $_{1}$;

- inflation as a variable for macroeconomic instability (Inflation $\left.{ }_{i t}\right)$, and

- the real interest rate ( Interest $_{i t}$ ).

We used the one-period lag of growth in order to avoid a potential endogeneity problem as in the studies by Wang (2010) and Jude (2014). The influence of the crowding-out or crowding-in effects of C-B M\&As on domestic investment was considered on the basis of the signs and magnitudes of the $\beta_{2}$ coefficient. If this coefficient is positive and significant $\left(\beta_{2}>0\right)$, then an increase in C-B $M \& A$ s produces a crowding-in effect and vice versa. On the other hand, the crowding-out of domestic investment occurs if the estimated coefficient is negative and significant $\left(\beta_{2}<0\right)$.

As our base proxy variable for a country's progress in transition, we used an overall structural reform indicator (REF) constructed from the EBRD indices of structural reforms. Since all the EBRD indices are highly correlated with each other (large-scale privatization, smallscale privatization, governance and enterprise restructuring, price liberalization, trade and foreign exchange system, and competition policy), the use of one composite structural index removes problems which could occur due to multicollinearity. The values of these indicators can range from 1, implying little progress, to 4.3 , indicating standards and the performance of advanced market economies. These indicators reflect expert opinion on country-specific reform developments in transition countries. They are useful for monitoring and tracking the progress of countries on their way towards a market economy. The source of this data is the EBRD, which has been assessing the progress of structural change since 1989.

The overall structural reform indicator was obtained with the help of the Principal Component Analysis (PCA) method. This technique was used to reduce the number of variables of interest into a smaller set of components. In this way, we acquired information on the overall quality of the structural reforms in the surveyed countries annually. The main argument in favour of an overall indicator instead of particular structural reform indicators is that foreign investors take into account various institutional factors that affect their decisions. We included the interaction variable in order to assess the joint effect of C-B M\&As and the progress of structural reform on macroeconomic performance.

We also added a dummy variable in order to evaluate the efficiency of structural reforms achieved during the first decade of transition. The average level of the total EBRD indicator (quantifying progress in six areas) for 1990-1999 was used as a criterion for the classification of countries (see Table 1). For instance, the dummy variable D1 distinguishes countries with faster structural change and takes the value 1 if a country is a radical reformer with a total EBRD indicator above 3, and 0 otherwise (a slow and moderate reformer). The time 
reform variable refers to the number of years required to achieve the average EBRD transition indicator, which amounts to 3.

The second generation reform variable (SGR) was also included in our dynamic panel model specifications. This variable represents an average of three indices (large-scale privatization, governance and enterprise restructuring, and competition policy) related to the reform areas that require more attention from policy-makers due to their complexity. The so-called "second generation" means that transition countries have achieved macroeconomic stabilization and market liberalization and, therefore, established a good basis for further steps of the process of structural adjustment. They are also referred as measures for deepening and sustaining market-oriented reforms whose implementation were of crucial importance for those transition countries strived to become an EU member. It is worth noting that while the first phase of reforms (comprises the remaining three EBRD indices) could be implemented relatively quickly, the second generation reforms require more time and efforts from transition countries.

Table 1. Reform-effort classification of countries included in the sample for the period 1990-1999 (source: based on the authors calculations)

\begin{tabular}{|l|l|}
\hline \multicolumn{1}{|c|}{ Sub-samples } & \multicolumn{1}{c|}{ Countries } \\
\hline Radical reformers & Hungary, Czech Republic, Poland, Slovakia \\
\hline $\begin{array}{l}\text { Moderate and slow } \\
\text { reformers }\end{array}$ & $\begin{array}{l}\text { Albania, Armenia, Bulgaria, Croatia, Estonia, Georgia, Latvia, Lithuania, } \\
\text { Macedonia, Moldova, Romania, Russia, Slovenia, Belarus, Bosnia and } \\
\text { Herzegovina, Montenegro, Serbia and Ukraine }\end{array}$ \\
\hline
\end{tabular}

The data for C-B M\&As (expressed as a percentage of GDP) was obtained from the UNCTAD FDI database. The source of data for GDP per capita, domestic credit to the private sector, real GDP growth, inflation measured by Consumer Price Index (annual \%), and the real interest rate was the World Bank. Domestic Investment was calculated as the difference between Gross Fixed Capital Formation and inward FDI also based on data obtained from the same source. The data for governance balance was obtained from the EBRD and Eurostat. Initial conditions in transition countries are presented with the help of data on Purchasing Power Parity (PPP) Income per capita in 1989, which comes from the IMF (2000) publication (except for Serbia, Bosnia and Herzegovina, and Montenegro, which is based on the author's calculations).

We applied a system Generalized Method of Moment (GMM) estimator on panel data set compiled from annual observations of 22 European transition countries in the 2000-2014. We opted for the Blundell-Bond system GMM estimator since it allows us to generate consistent estimates under condition of endogeneity and omitted variables. It implies the existence a system of original and transformed equations (Roodman 2009). This estimator is superior to the difference GMM estimator when dealing with time-invariant regressors, random-walk variables and panel with gaps. According to Blundell and Bond (1998), results on the basis of the difference GMM estimator should be taken with a certain amount of reserve due to the possibility of short sample periods and persistent series (Blundell, Bond 1998). Under 
such circumstances, the estimator is characterized by a large sample bias and imprecision. In order to limit the number of instruments, we used collapse option and restrict the lag ranges of endogenous variables used in GMM-style instruments. We applied "Windmeijer finite sample correction" for standard errors in order to evaluate the precision of the two-step estimators (Windmeijer 2005).

We examined the consistency of this econometric technique with the help of two specification tests. The validity of the instruments was tested using a Hansen test of over-identifying restrictions which is robust to heteroskedasticity. We also checked for second-order serial correlation of the residuals. In order to calculate the coefficients and standards errors for long term impacts we followed the method proposed by Papke and Wooldridge (2005). Data processing was carried out using STATA software packages version 12.

\section{Empirical results}

Table 2 presents the estimation results for the economic effect of C-B M\&As on GDP per capita, whose coefficients are in line with theoretical expectations. The p-values of the Hansen test statistic in all regressions range from 0.340 to 0.605 , which indicate that our instruments are not correlated with the errors. The Arellano-Bond test on the residuals in the first differences reveals the absence of second-order serial correlation. Taking into consideration the results of our diagnostic tests, we conclude that our model is appropriate specified. The value of the lagged GDP per capita is less than unity and it is highly statistically significant in all equations, suggesting the convergence. The current C-B M\&As appear negative and significant at the $10 \%$ level in 3 out of 4 regressions. On the other hand, our empirical findings indicate that their lagged level has a positive effect on GDP per capita one year later. The significance of their lagged value is robust to changes in variables and their coefficients range between 0.013 and 0.016 . This means that this type of FDI requires at least a year to make a positive contribution to the recipient country. These coefficients are relatively stable and significant in all regressions.

We observe that the coefficients of the budget balance are positive and highly significant. This variable is consistently positive and remains significant, independently of the other variables involved in models. The coefficients of Income are negative in 3 out of 4 columns, but not significant at conventional levels. Domestic investment has a positive impact on the GDP per capita but also insignificant in all specifications. Domestic credit to private sector, as a measure of financial development, has positive and statistically significant impact on GDP per capita in almost all specification in Table 2.

According to our findings, the GDP per capita was significantly affected by the quality of structural reforms measured by composite EBRD indicator. We found enough evidence that progress in structural reforms is important in achieving higher GDP per capita as in empirical study by Efendić et al. (2010) and Beck and Leaven (2006). The interaction term between overall structural reform indicator and C-B M\&As is negative but not statistically significant. In regression 2, we replaced the overall structural reform indicator with the time reform variable and obtained a coefficient which is negative and statistically significant as was expected. Every additional year spent implementing structural reforms 
Table 2. Economic effect of C-B M\&As on GDP per capita (source: authors calculations)

\begin{tabular}{|c|c|c|c|c|}
\hline Variables & 1 & 2 & 3 & 4 \\
\hline $\operatorname{lngdppc}(-1)$ & $0.762^{\star \star \star}(0.067)$ & $0.774^{\star * \star}(0.076)$ & $0.732^{\star \star \star}(0.077)$ & $0.734^{* * *}(0.077)$ \\
\hline M\&As & $-0.054^{\star} \quad(0.032)$ & $-0.073 \quad(0.049)$ & $-0.079^{\star} \quad(0.045)$ & $-0.049^{*} \quad(0.027)$ \\
\hline M\&As $(-1)$ & $0.013^{* *}(0.006)$ & $0.016^{\star \star}(0.006)$ & $0.015^{\star \star} \quad(0.006)$ & $0.013^{\star *} \quad(0.005)$ \\
\hline Budget & $0.019^{\star * *}(0.004)$ & $0.018^{\star * \star}(0.004)$ & $0.022^{* * *}(0.004)$ & $0.020^{* * *}(0.005)$ \\
\hline $\mathrm{DI}$ & $0.009 \quad(0.009)$ & $0.017 \quad(0.018)$ & $0.020 \quad(0.013)$ & $0.012 \quad(0.010)$ \\
\hline Income & $\begin{array}{ll}0.042 \quad(0.080) \\
\end{array}$ & $-0.125 \quad(0.132)$ & $-0.011 \quad(0.068)$ & $-0.003 \quad(0.078)$ \\
\hline Credit & $0.002^{*} \quad(0.001)$ & $0.003 \quad(0.001)$ & $0.004^{\star \star}(0.002)$ & $0.003^{\star} \quad(0.002)$ \\
\hline REF & $0.040^{* *} \quad(0.017)$ & & & \\
\hline $\mathrm{REF}^{*} \mathrm{M} \& \mathrm{As}$ & $-0.005 \quad(0.011)$ & & & \\
\hline Years of reform & & $-0.010^{\star \star}(0.005)$ & & \\
\hline D1 & & & $0.275^{\star * \star}(0.081)$ & \\
\hline SGR & & & & $0.182^{* *}(0.074)$ \\
\hline Time Effect & Yes & yes & yes & yes \\
\hline No. of Obs. & 304 & 304 & 304 & 304 \\
\hline No. of groups & 22 & 22 & 22 & 22 \\
\hline $\begin{array}{l}\text { No. of instru- } \\
\text { ments }\end{array}$ & 18 & 17 & 17 & 17 \\
\hline $\begin{array}{l}\text { Hansen test } \\
\text { ( } \mathrm{p} \text { value) }\end{array}$ & 0.340 & 0.451 & 0.605 & 0.294 \\
\hline $\begin{array}{l}\mathrm{AR}(2) \\
\text { (p value) }\end{array}$ & 0.469 & 0.534 & 0.572 & 0.371 \\
\hline
\end{tabular}

Note: Standard errors are in parentheses. ${ }^{* *},{ }^{* *}$, and ${ }^{*}$ indicate significance at $1 \%, 5 \%$ and $10 \%$, respectively.

so as to reach the average EBRD indicator (which amounts to 3 ) has a negative impact on GDP per capita.

We also found that countries which undertook comprehensive structural reforms during the first decade of their transition achieved a positive impact on GDP per capita (see Table 1). Those countries seeking to join the EU and OECD achieved better results in the improvement of their institutional environment. They were encouraged to adapt common European legal and regulatory systems and accomplish all the necessary requirements for integration. These requirements were very similar to the conditions for a successful transition period. Hence, we conclude that there is no doubt that the European perspective was a crucial incentive for the further implementation of structural reforms. We also revealed that the efforts in implementing second generation structural reforms have positively reflected on output performance in transition countries.

Table 3 displays the results of the effect of C-B M\&As and their interaction with structural reforms on domestic investment when controlling for other macroeconomic variables. The $\mathrm{p}$-values of the Hansen test statistics for all specifications range from 0.599 to 0.760 
which clearly indicates that the instruments are valid. In addition, we do not find evidence of second-order serial correlations in the differenced residuals. The signs of the coefficients of the variables in Table 3 are largely as expected. The coefficients of the lagged dependent variable have values which are less than unity suggesting the existence of the convergence process. This variable has positive and highly significant coefficients in which provide support for convergence process.

Table 3. Economic effect of C-B M\&As on domestic investment (source: authors calculations)

\begin{tabular}{|c|c|c|c|c|}
\hline Variables & 1 & 2 & 3 & 4 \\
\hline DI $(-1)$ & $0.473^{\star * *}(0.088)$ & $0.486^{* * *}(0.076)$ & $0.481^{* * *}(0.087)$ & $0.470^{\star * *} \quad(0.085)$ \\
\hline M\&As & $-0.598 \quad(0.445)$ & $-0.571 \quad(0.450)$ & $-0.477 \quad(0.500)$ & $-0.474 \quad(0.483)$ \\
\hline M\&As $(-1)$ & $0.326^{* *}(0.140)$ & $0.323^{\star *}(0.141)$ & $0.314^{* *}(0.143)$ & $0.323^{\star *} \quad(0.323)$ \\
\hline Growth $(-1)$ & $0.089^{*}(0.048)$ & $\begin{array}{ll}0.079 \quad(0.049) \\
\end{array}$ & $0.078 \quad(0.047)$ & $0.081^{*}$ \\
\hline Inflation & $-0.052 \quad(0.050)$ & $-0.046 \quad(0.038)$ & $-0.052 \quad(0.033)$ & $-0.028 \quad(0.050)$ \\
\hline Interest & $-0.104^{\star \star}(0.044)$ & $-0.102^{\star \star}(0.043)$ & $-0.100^{* *}(0.043)$ & $-0.089^{*} \quad(0.047)$ \\
\hline REF & $0.041 \quad(0.481)$ & & & \\
\hline $\mathrm{REF}^{*} \mathrm{M} \& \mathrm{As}$ & $0.115 \quad(0.099)$ & & & \\
\hline Years of reform & & $-0.047 \quad(0.137)$ & & \\
\hline D1 & & & $0.142 \quad(1.072)$ & \\
\hline SGR & & & & $(1.227)$ \\
\hline Time effect & Yes & Yes & Yes & Yes \\
\hline No. of Obs. & 266 & 266 & 266 & 266 \\
\hline No. of groups & 22 & 22 & 22 & 22 \\
\hline $\begin{array}{l}\text { No. of instru- } \\
\text { ments }\end{array}$ & 14 & 13 & 13 & 13 \\
\hline $\begin{array}{l}\text { Hansen test } \\
\text { (p value) }\end{array}$ & 0.599 & 0.711 & 0.700 & 0.760 \\
\hline $\begin{array}{l}\mathrm{AR}(2) \\
\text { ( } \mathrm{p} \text { value) }\end{array}$ & 0.777 & 0.727 & 0.703 & 0.726 \\
\hline
\end{tabular}

Note: Standard errors are in parentheses. ${ }^{* *},{ }^{* *}$, and ${ }^{*}$ indicate significance at $1 \%, 5 \%$ and $10 \%$, respectively.

The current C-B M\&As have a negative but highly insignificant coefficients in all columns. On the other hand, the lagged C-B M\&As positively affect the domestic investment in transition countries. These coefficients are statistically significant at the $5 \%$ level suggesting that spillover effects of this type of investment could be expected later (one year after merger or acquisition). The significance of their lagged value is robust to inclusion of other variables and their coefficients are in the range between 0.314 and 0.326 . Hence, we confirm the results of Adams (2009) and Wang (2010) who find that the coefficient of lagged FDI inflows is significant with a positive sign, indicating that domestic firms enjoy benefits from foreign presence over time. 
The estimated coefficients on the one-year lagged GDP growth have the predicted sign which is statistically significant in column 1 and 4 . The coefficient of the inflation variable is negative, but not statistically significant in any of the specifications. As expected, the real interest rate has negative sign and is significant at the 5 and $10 \%$ levels. Therefore, we conclude that the real interest rate variable is an important factor in explaining domestic investment activity.

The contribution of overall structural reform indicator, as well as its interaction with $\mathrm{C}-\mathrm{B}$ M\&As, to domestic investment is positive but the coefficients are not statistically significant. Although, the signs of the coefficients of dummy variable (D1) and transition time variable are as expected, they turn out to be insignificant. Regarding the effect of second generation reforms on domestic investment, we found that this variable does not have any explanatory power. The coefficient has the predicted sign, but it is highly insignificant. Therefore, we conclude that advances in structural reforms did not have noticeable influence on domestic investment activity in transition countries.

The estimated coefficients of C-B M\&As and variables of structural change in the previous tables enable inferences to be drawn regarding their short-term effects. However, in order to get the true picture of their importance to GDP per capita and domestic investment, it is crucial to consider their effect over time. In regards to the long-term effect of C-B M\&As on GDP per capita (based on the regression model with the overall structural reform indicator in the first column of Table 2), the coefficient is negative and significant at the $10 \%$ level, but insignificant at the 5\% level (-0.183), (see Table 4 ). The overall structural reform indicator has a positive and significant influence on economic performance, while its interaction with C-B M\&As is negative but not significant.

Table 4. Long-run effect of changes in independent variables on GDP per capita and domestic investment (source: authors calculations)

\begin{tabular}{|c|c|c|}
\hline \multirow{2}{*}{ Long-run coefficient } & \multicolumn{2}{|c|}{ Dependent variable } \\
\hline & GDP per capita & Domestic investment \\
\hline M\&As & $-0.183^{\star}(0.102)$ & $-1.138(0.944)$ \\
\hline REF & $0.122^{\star * *}(0.039)$ & $0.078 \quad(0.906)$ \\
\hline $\mathrm{REF}^{\star} \mathrm{M} \& \mathrm{As}$ & $-0.023 \quad(0.039)$ & $0.218 \quad(0.208)$ \\
\hline
\end{tabular}

Note: Standard errors are in parentheses. ${ }^{* *},{ }^{* *}$, and ${ }^{*}$ indicate significance at the $1 \%, 5 \%$ and $10 \%$, respectively. The coefficients were calculated using the "nlcom" command in Stata 12. These results are based on the $1^{\text {st }}$ column of Tables 2 and 3 .

According to the results in Table 4, none of the long-term coefficients (based on regression model with the structural reform indicator in Table 3) seem statistically significant at the conventional level of 0.10 . Our results show that structural reforms and their interaction with C-B M\&As did not contribute to domestic investment since their impacts were insignificant. The influence of C-B M\&As is negative but also insignificant. 


\section{Conclusions}

Our empirical findings indicate that current C-B M\&As had a negative effect on GDP per capita while the influence of their one-year lagged level was positive and significant. Negative effect of C-B M\&As on GDP per capita in the year of merger or acquisition could be explained by the foreign investors' engagement in capital intensive industries and decrease in production due to inevitable technological and management restructuring (or the liquidation of the financially unstable companies). On the other hand, the lagged level of C-B M\&As turned out to be positive and significant, which leads to the conclusion that this form of FDI might have a delayed mid-term effect. Increase in GDP per capita could arise from interrelation between domestic and foreign companies, in particular, technology spillovers. The improvement of functioning, organizational change and the growth in efficiency could be expected only in medium-term, taking into consideration structural inertia of former socialist enterprises. However, C-B M\&As have negative and significant effect on GDP per capita in long-term perspective. We argue that some foreign investors tend to reduce production capacity and the number of employees in the long run or even opt to relocate their production facility in countries with competitive advantages.

We found that persistence in implementation of structural reforms results in an increase of the economic potential and the competitiveness of transition countries. On the other hand, their interaction term with C-B M\&As is negative but not significant in current period. We found that every additional year a country spends implementing economic reforms so as to reach the standard of an industrialised market economy has a negative effect on GDP per capita. The results also indicated that countries which undertook the greatest structural reforms during the first decade of their transition achieved a positive impact on GDP per capita. We also revealed that the pursuit of second generation reforms resulted in higher GDP per capita.

As for impact of C-B M\&As on domestic investment, we found that in the year of transaction and in long-term period the effects are negative and statistically insignificant. On the other hand, lagged C-B M\&As positively affect domestic investment in transition countries (coefficients are highly statistically significant). It means that spillover effects of this type of investment can be expected not earlier than one year after the merger or acquisition. We can assume that the most competitive and financially stable domestic companies can temporarily benefit from the presence of foreign enterprises on the local market. It is worth noting that structural reform and its interaction with C-B M\&As did not prove significant for encouraging domestic investment in European transition countries. In addition, nor was the speed of reform implementation important for domestic investment.

This paper makes several contributions to the literature. On the basis of a deeper insight into the literature, we found that the influence of $\mathrm{C}-\mathrm{B} \mathrm{M} \& \mathrm{As}$ on macroeconomic performance in transition countries has not been sufficiently explored. We contribute to existing research by investigating the dynamic nature of cross-border mergers and acquisitions and their economic effects on GDP per capita and domestic investment depending on the quality of structural reforms. Our intention was to discover wheather structural reforms represent the right channel through which the positive impact of C-B M\&As may be transmitted to GDP per capita and domestic investment in the short and long run. 
This paper differs from existing studies on C-B M\&As since it focuses on structural development efficiency (since the beginning of transition) as one of determinant of the economic effects of C-B M\&As. By distinguishing countries with faster institutional change from those relied on gradual approach, we determined the extent of influence of structural reforms on GDP per capita and domestic investment.

The main limitation of our research is that we relied on EBRD indicators which are selective and do not cover all important dimensions of the transformation process. We believe that the main disadvantage of the EBRD data is that it only reflects expert opinion on a few different areas of institutional quality. In addition, a C-B M\&A transaction may only be the first in a series and might be followed by extensive portfolio capital transactions and international loans. Hence, the possible economic effects of C-B M\&As alone could be overestimated. We also did not consider special measures employed by the governments of host countries trying to enhance the positive economic effects of C-B M\&As after transactions were completed. Furthermore, our data set could not be expanded since the majority of countries, especially those from the SEE region, started to record this type of FDI only at the beginning of the 2000s (due to economic, social and political developments in these countries).

Our empirical research could be extended and enriched by observing the economic effects of C-B M\&As and total FDI inflows at the macroeconomic level. We also argue that it may be possible to include different aspects of formal and informal institutions and observe the impact of their interaction with C-B M\&As. By comparing their influence on the economic effects of this type of FDI, we could determine which of these two institutional domains has had a greater impact on macroeconomic performance in host countries in transition. In addition, it could be rather important to consider the complementarity between C-B M\&As and separate structural reform indicators. Based on these results, one can identify certain areas of structural policy so as to bring about positive economic effects from C-B M\&As.

\section{References}

Adams, S. 2009. Foreign direct investment, domestic investment, and economic growth in Sub-Saharan Africa, Journal of Policy Modeling 31(6): 939-949. https://doi.org/10.1016/j.jpolmod.2009.03.003

Albulescu, C. T. 2015. Do foreign direct and portfolio investments affect long-term economic growth in Central and Eastern Europe?, in $2^{\text {nd }}$ Global Conference on Business, Economics, Management and Tourism, 30-31 October, 2014, Prague, Czech Republic.

https://doi.org/10.1016/S2212-5671(15)00539-0

Alguacil, M.; Cuadros, A.; Orts, V. 2011. Inward FDI and growth: the role of macroeconomic and institutional environment, Journal of Policy Modelling 33(3): 481-496.

https://doi.org/10.1016/j.jpolmod.2010.12.004

Amighini, A.; McMillan, S.; Sanfilippo, M. 2017. FDI and capital formation in developing economies: new evidence from industry-level data. NBER Working Papers Series 23049.

Ashraf, A.; Herzer, D. 2014. The effects of greenfield investment and M\&As on domestic investment in developing countries, Applied Economics Letters 21(14): 997-1000.

https://doi.org/10.1080/13504851.2014.904482

Azman-Saini, W. N. W.; Baharumshah, A. Z.; Law, S. H. 2010. Foreign direct investment, economic freedom and economic growth: international evidence, Economic Modelling 27(5): 1079-1089. https://doi.org/10.1016/j.econmod.2010.04.001 
Beck, T.; Laeven, L. 2005. Institution building and growth in transition economies. Policy Research Working Paper 3657. Washington, DC: World Bank.

Blundell, R.; Bond, S. 1998. Initial conditions and moment restrictions in dynamic Panel Data Models, Journal of Econometrics 87(1): 115-143. https://doi.org/10.1016/S0304-4076(98)00009-8

De Melo, M.; Denizer, C.; Gelb, A.; Tenev, S. 1997. Circumstance and choice: the role of initial conditions and policies in transition economies. Policy Research Working Paper Series 1866. Washington, DC: World Bank.

EBRD. 2015. Economic data [online], [cited 15 February 2015]. European Bank for Reconstruction and Development. Available from Internet: http://www.ebrd.com/what-we-do/economic-researchand-data/data.html

Efendić, A.; Geoff, P.; Adnett, N. 2010. Institutions and economic performance: system GMM modelling of institutional effects in transition [online], [cited 23 June 2016]. Available from Internet: http:// riinvestinstitute.org/pdf/Efendic_et_al.pdf

Eren, M.; Zhuang, H. 2015. Mergers and acquisitions versus greendfield investment, absorptive capacity, and economic growth: evidence from 12 new member states of the European Union, Eastern European Economics 53(2): 99-123. https://doi.org/10.1080/00128775.2015.1033240

Farla, K.; de Combruggher, D.; Vertspagen, B. 2016. Institutions, foreign direct investment, and domestic investment: crowding out or crowding in?, World Development 88: 1-9. https://doi.org/10.1016/j.worlddev.2014.04.008

Gocer, İ.; Mercan, M.; Peker, O. 2014. Effect of foreign direct investments on the domestic investments of developing countries: a dynamic Panel Data Analysis, Journal of Economic and Social Studies 4(1): 73-90. https://doi.org/10.14706/JECOSS11415

Herzer, D. 2012. How does foreign direct investment really affect developing countries' growth?, Review of International Economics 20(2): 396-414. https://doi.org/10.1111/j.1467-9396.2012.01029.x

Hlavacek, P.; Bal-Domanska, B. 2016. Impact of foreign direct investment on economic growth in Central and Eastern European countries, Engineering Economics 27(3): 294-303.

https://doi.org/10.5755/j01.ee.27.3.3914

IMF. 2000. World economic outlook: focus on transition economies. Washington, DC: International Monetary Fund.

Jude, C. 2014. Does FDI crowd out domestic investment in transition countries [online], [cited 25 May 2016]. Available from Internet: http://www.touteconomie.org/afse2014/index.php/meeting2014/ lyon/paper/viewFile/86/44

Jude, C.; Levieuge, G. 2017. Growth effect of FDI in developing economies: the role of institutional quality, The World Economy 40(4): 715-742. https://doi.org/10.1111/twec.12402

Kosova, R. 2010. Do foreign firms crowd out domestic firms? Evidence from the Czech Republic, Review of Economics and Statistics 92(4): 861-881. https://doi.org/10.1162/REST_a_00035

Kulikova, N.; Lobanov, M. 2011. The role of FDI in the economic modernization of Central and Eastern European EU member states: view from Russia, in M. Antevski (Ed.). Development potentials of foreign direct investment: international experience. Belgrade: Institute of International Politics and Economics.

Mileva, E. 2008. The impact of capital flows on domestic investment in transition economies. Working Paper Series 871. European Central Bank.

Papke, L. E.; Wooldridge, J. M. 2005. A computational trick for Delta-method standard errors, Economics Letters 86(3): 413-417. https://doi.org/10.1016/j.econlet.2004.07.022

Pegkas, P. 2015. The impact of FDI on economic growth in Eurozone countries, The Journal of Economic Asymmetries 12(2): 124-132. https://doi.org/10.1016/j.jeca.2015.05.001 
Pilbeam, K.; Oboleviciute, N. 2012. Does foreign direct investment crowd in or crowd out domestic investment? Evidence from the European Union, The Journal of Economic Asymmetries 9(1): 89-104. https://doi.org/10.1016/j.jeca.2012.01.005

Polterovich, V. 2008. Institutional trap, in S. N. Durlauf, L. E. Blume (Eds.). The new Palgrave dictionary of economics. New York: Palgrave Macmillan. https://doi.org/10.1057/978-1-349-95121-5_2717-1

Polterovich, V.; Popov, V. 2007. Democratization, quality of institution and economic growth. Tiger Working Paper 102.

Roodman, D. 2009. How to do xtabond2: an introduction to "difference" and "system" GMM in stata, Stata Journal 9(1): 86-136.

Sikharulidze, D.; Tordinava, T.; Kurdadze, S. 2015. The impacts of FDI on domestic investment (in case of Georgia), Social and Economic Revue 13(1): 35-40.

Szkorupová, Z. 2015. Relationship between foreign direct investment and domestic investment in selected countries of Central and Eastern Europe, in $2^{\text {nd }}$ Global Conference on Business, Economics, Management and Tourism, 30-31 October 2014, Prague, Czech Republic. https://doi.org/10.1016/S2212-5671(15)00350-0

Tan, B. W.; Goh, S. K.; Wong, K. N. 2016. The effects of inward and outward FDI on domestic investment: evidence using panel data of ASEAN-8 countries, Journal of Business Economics and Management 17(5): 717-733. https://doi.org/10.3846/16111699.2015.1114515

UNCTAD. 2003. World investment report 2003: FDI policies for development: national and international perspectives. New York and Geneva: United Nations publications.

United Nations. 2003. Monterrey consensus on financing for development. United Nations: New York.

Wang, M. 2010. Foreign direct investment and domestic investment in the host country: evidence from panel study, Applied Economics 42(29): 3711-3721. https://doi.org/10.1080/00036840802314580

Windmeijer, F. 2005. A finite sample correction for the variance of linear efficient two-step GMM estimators, Journal of Econometrics 126(1): 25-51. https://doi.org/10.1016/j.jeconom.2004.02.005

World Bank. 2015. World Development Indicators database [online], [cited 10 April 2015]. Available from Internet: http://databank.worldbank.org/data/reports.aspx?source=world-development-indicators 